\title{
Landslide Risk Mapping in an Urban Area of the City of Natal, Brazil
}

\author{
Laddyla Bezerra $^{1, *(\mathbb{D}}$, Osvaldo de Freitas Neto ${ }^{1}\left(\mathbb{D}\right.$, Olavo Santos Jr. $^{1}(\mathbb{D}$ and \\ Slobodan Mickovski ${ }^{2}$ D \\ 1 Graduate Program in Civil Engineering (PEC-UFRN), Federal University of Rio Grande do Norte, \\ Campus Universitário, Natal, RN 59078-970, Brazil; osvaldocivil@ufrn.edu.br (O.d.F.N.); \\ olavo.santos@ufrn.edu.br (O.S.J.) \\ 2 Department of Civil Engineering and Environment, School of Computing, Engineering and Built Environment, \\ Glasgow Caledonian University, Glasgow G4 0BA, UK; slobodan.mickovski@gcu.ac.uk \\ * Correspondence: laddyla@ufrn.edu.br; Tel.: +55-84996943343
}

Received: 17 September 2020; Accepted: 16 November 2020; Published: 18 November 2020

check for updates

\begin{abstract}
Landslides are part of the natural processes of Earth's surface dynamic, which could be accelerated or triggered by anthropic interference. Inadequate occupation of areas highly susceptible to landslide processes is the principal cause of accidents on Brazilian urban slopes, especially those occupied by settlements and slums. In Natal, Rio Grande do Norte state, Brazil, the existence of areas with steep and densely occupied slopes makes the municipality susceptible to landslides. In this context, the present study aimed to map the risk of landslides in an urban area located in the city of Natal. Using the quali-quantitative model proposed by Faria (2011), adapted for the conditions of the study area, which applies a multicriteria analytical hierarchy process (AHP) to a Geographic Information System (GIS), 11 risk indicators were submitted to pairwise comparisons by 10 risk management specialists in order to determine the relative importance (weighting) for each of these factors as a function of their contribution to the risk. The weightings obtained were combined to produce the final risk map of the study area, using a map algebra framework. The results show the existence of a critical risk for the resident population, primarily related to the possibility of a landslide, with potentially negative economic, environmental, and mainly social impacts.
\end{abstract}

Keywords: risk; hazard; vulnerability; landslides; multicriteria assessment; analytical hierarchy process

\section{Introduction}

In recent decades, there has been a considerable increase in the frequency, intensity, and impacts generated by socioenvironmental disasters worldwide [1]. According to the World Disaster Report 2010, with a focus on urban risks, 4014 natural disasters occurred around the world between 2000 and 2009 , affecting more than one million people. In Brazil, a report prepared by [2] revealed that $22 \%$ of the socioenvironmental disasters recorded between 1991 and 2012 occurred in the 1990s, 56\% between 2000 and 2009, and 22\% in just three years (between 2010 and 2012). The document also indicates an increase in the number of disasters associated with landslides between 1990 and 2000. According to [3], this significant increase in the number of landslides on Brazilian slopes is caused primarily by the lack of urban planning and infrastructure. The latter fact has led the most underprivileged individuals to occupy naturally unsuitable areas or those that are highly susceptible to unstable slopes, mostly as a result of the low real estate value of the land.

Unsuitable occupation of areas susceptible to landslides in the city of Natal, Brazil, has made them vulnerable to slope instability. In 2014, two great magnitude natural disasters associated with intensity of rainfall were recorded in the districts of Mãe Luiza and Rocas, within Natal. The accidents 
were characterized, respectively, as sand flow on dune area and failure of the soil nail wall on Barreiras Formation sediment [4]. Both events had significant social and environmental impacts. To mitigate or even prevent future socioenvironmental disasters similar to those described above from happening, new research projects dedicated to the study of risk areas are needed.

Risk analysis can be carried out either through a qualitative, quali-quantitative or quantitative approach [5]. Risk mapping in Brazil and many other countries predominantly uses qualitative methodologies [6]. This type of assessment is based on professional judgement via field observations, interpretation of aerial photographs, and information supplied by residents of the region under study. Many researchers believe that this leads to a certain subjectivity in the results obtained [7]. The outputs of quantitative methods, in turn, are numerical estimations, namely, the probability of occurrence of landslides and the probability distribution of consequences within a certain area. However, applications are restricted to localized studies in limited areas, by the necessity of a large volume of detailed data on the slopes, acquired with laboratory tests and field measurements. In the quali-quantitative methods, assessments consider that a number of factors influence stability. The scores attributed to each of these factors are used to evaluate how favorable or unfavorable they are to the occurrence of instability [8]. The last decade has seen an evolution of quali-quantitative analyses with a view to improve qualitative risk mapping. These reduce subjectivity, thereby increasing the hierarchization and prioritization of risk sectors. Ref. [9] proposed a quali-quantitative methodology based on the Analytical Hierarchy Process (AHP). The application of the AHP method in risk mapping makes the process more systematic and less subjective. The sensibility analyses used in the method allow for a higher perception of effectiveness in qualitative assessment and, as a result, a higher confidence level in decision-making [10].

The aim of the present study is to apply an adapted version of the methodology proposed by [9] in order to diagnose the occurrence of landslides in an area near the São José do Jacó settlement, in the city of Natal. The methodology used to achieve this aim was a multicriteria decision-making technique (AHP) and Geographic Information System (GIS) system for application at the local level. This approach includes the use of a limited number of key risk indicators and allows the delineation and mapping of risk zones with different associated risk levels which can help engineers and land planners to design and assess infrastructure and evaluate its effects on the surrounding environment.

\section{Materials and Methods}

\subsection{Quali-Quantitative Risk Assessment Model Proposed by Faria (2011)}

The AHP, developed by Saaty in the 1970s, proposes a method that could represent a decision-making process. The aim was to reach better conclusions based on a hierarchy, pairwise comparisons, judgement scales, weight and criterion attribution, and selection of the best alternatives for a finite number of variables [11]. Ref. [9] applied the multicriteria decision-making tool AHP to the risk mapping qualitative methodology adopted by [12]. This procedure gave rise to a hybrid methodology classified as quali-quantitative. The application of this approach includes three main stages: structuring, comparative judgements, and synthesis of priorities. These stages, as presented by [10], are shown on Figure 1.

The first step of the process involves deconstructing the problem into a hierarchical framework, organized by levels, with the problem-solving objective at the top and criteria to be assessed and their relevant alternatives in the decision process at the lower levels [13]. Figure 2 illustrates this stage.

In the comparative judgements stage, risk assessment specialists make a pairwise comparison between the criteria and alternatives to determine the relative importance (weighting) of each criterion. To this end, a number scale is needed to indicate how many times one element is more important than another, and the Saaty Fundamental Scale $[13,14]$ can be used for this purpose.

Finally, in the synthesis of priorities phase, the AHP calculates all the weightings of the hierarchical levels. The pairwise comparison matrix created is submitted to the eigenvector mathematical technique. Beforehand, they undergo sensitivity analysis to assess the coherence of the specialists' judgements. 


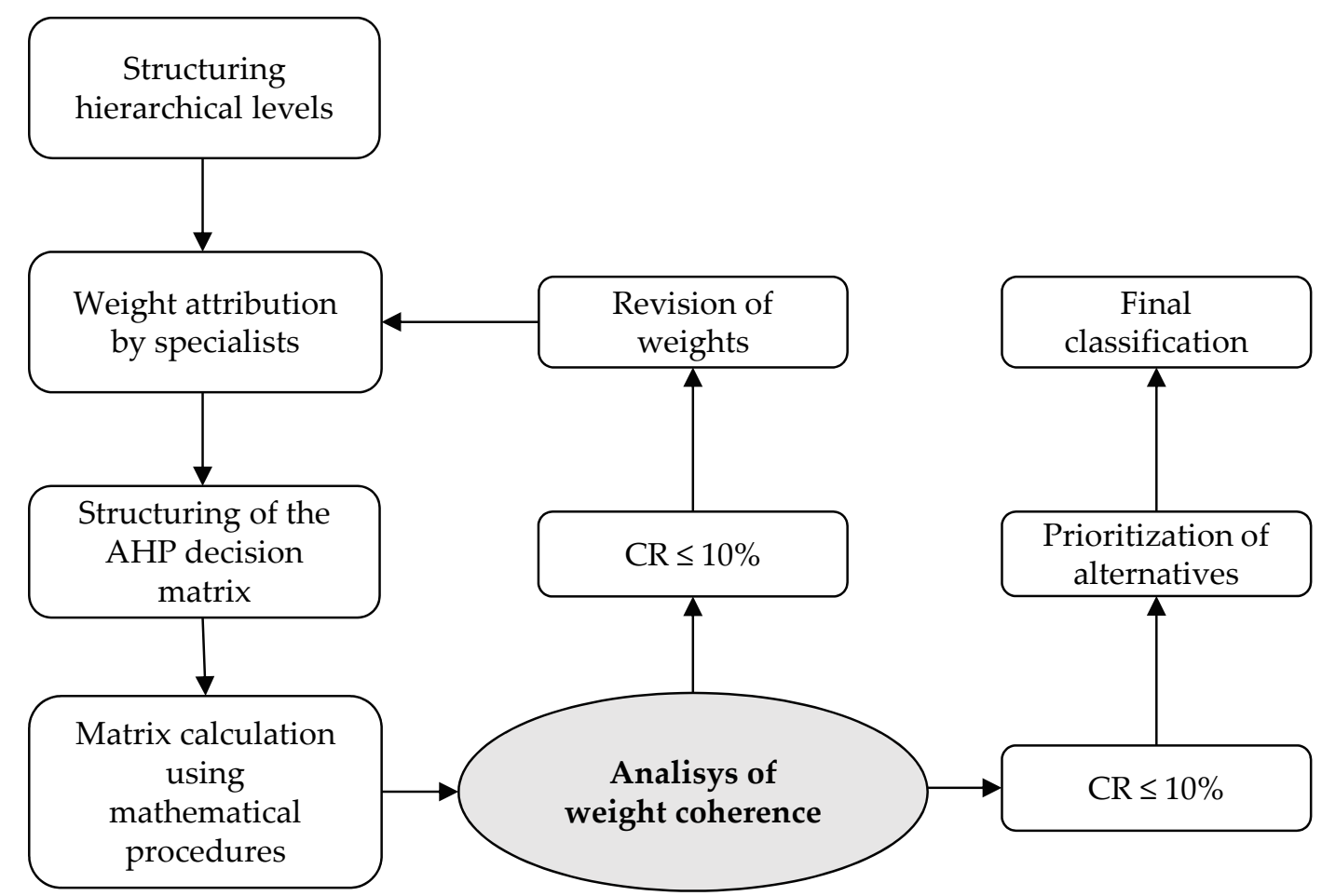

Figure 1. The main stages of the analytical hierarchy process (AHP) method. Adapted from [10].

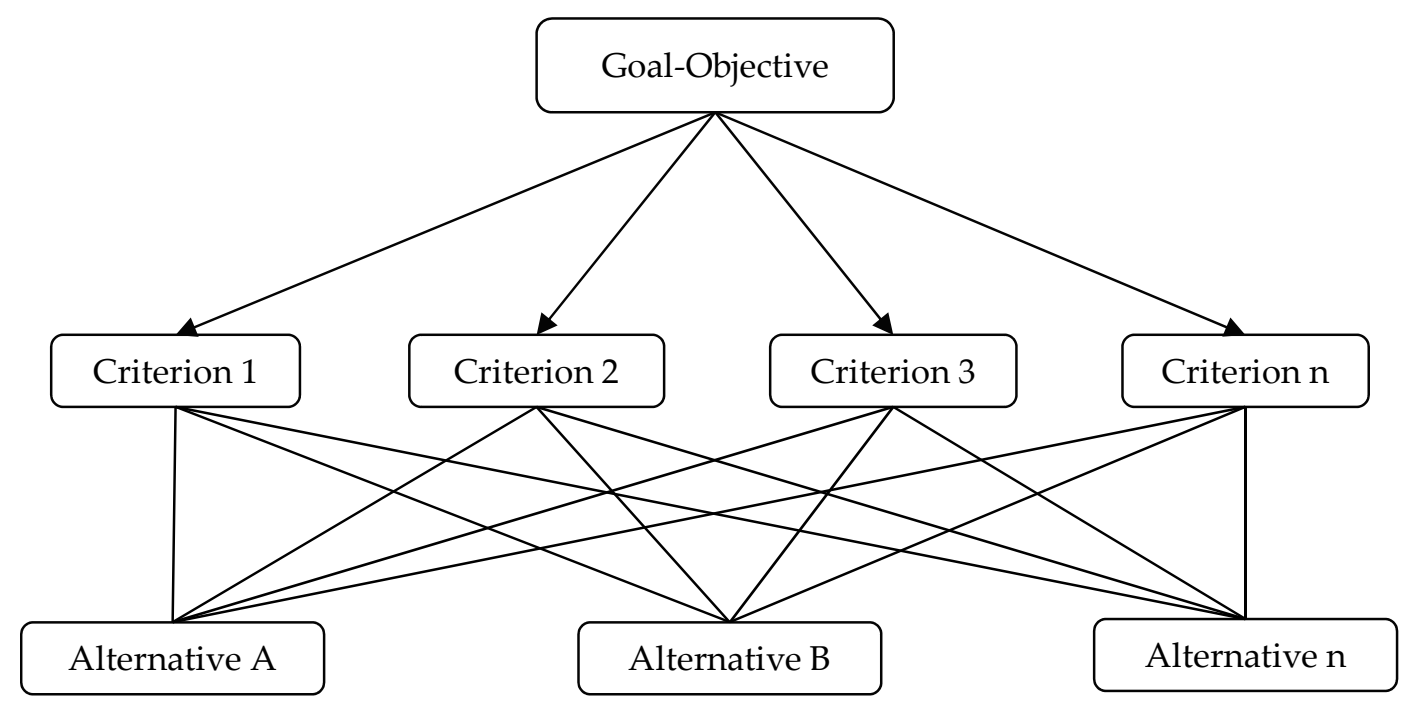

Figure 2. Example of the modeling or hierarchical structuring stage. Adapted from [13].

Ref. [15] recommend calculating the Consistency Ratio (CR), whose limit value at which judgements are considered inconsistent is $10 \%$. For CRs above the reference value, Ref. [15] suggests that the problem be studied and the attributed weightings be revised. The CR calculation procedure involves estimating the maximum eigenvalue $\left(\lambda_{\max }\right)$ and consistency index $(\mathrm{CI})$, as described by [15].

\subsection{Research Methodology}

The risk mapping for the present study was based on an adapted version of the quali-quantitative approach described by [9]. The adaptation mentioned occurred in the selection phase of socioenvironmental indicators, with the purpose of adapting the methodology to the specificities of the study area, as well as to the history of landslides known in the region of the municipality of Natal. 
The application of the proposed methodology considered 11 socioenvironmental indicators assessed as decisive in triggering landslides at the site, which were evaluated and characterized through technical inspection in homes, information provided by residents, aerial photography, and produced thematic maps. Figure 3 illustrates the indicators adopted in the study.

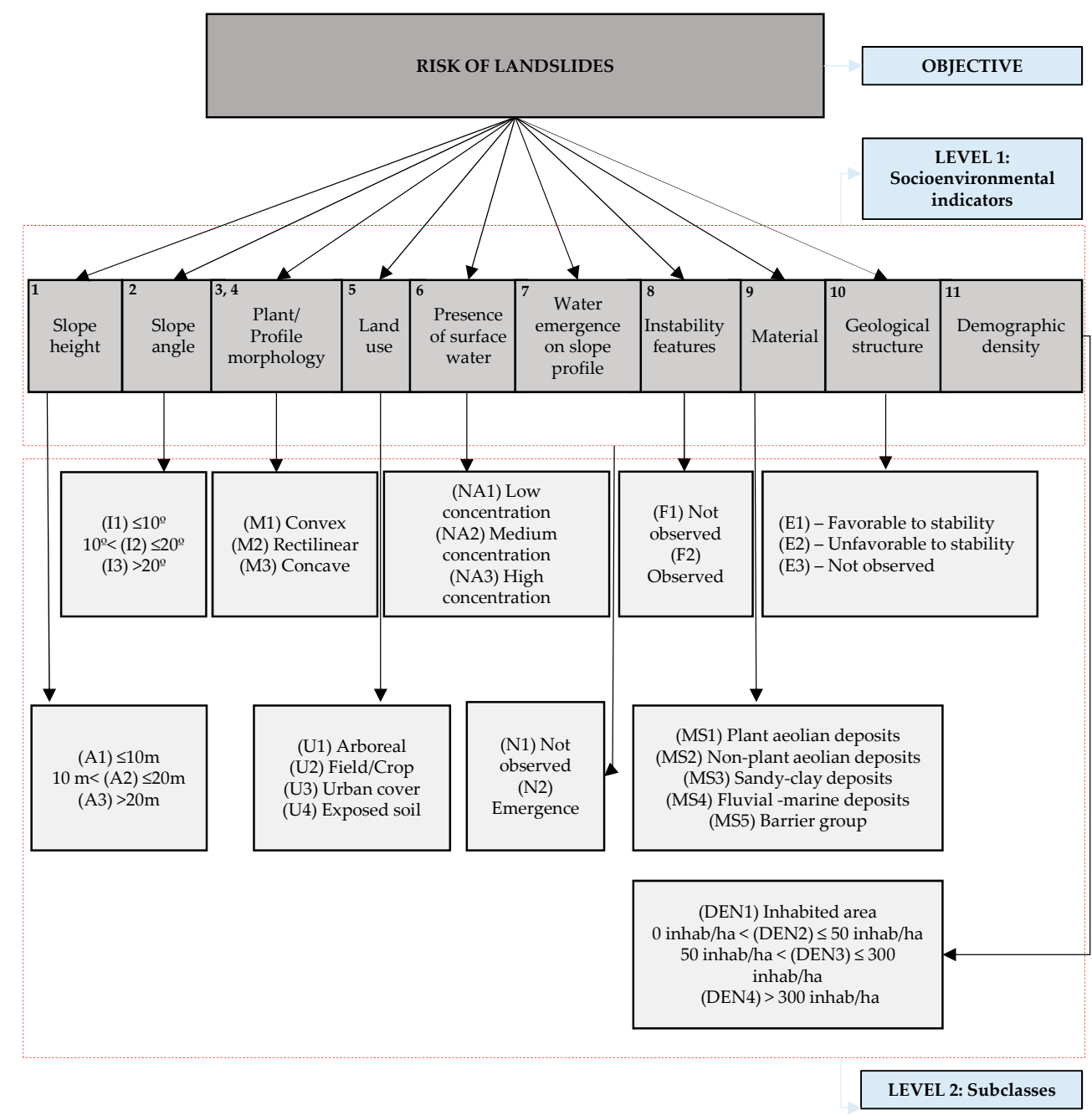

Figure 3. Hierarchical structure of the risk assessment approach adopted in the present study.

In choosing these socioenvironmental indicators, we sought to consider the natural and anthropic factors that affect slope stability. In terms of the former, the amplitude, inclination, slope morphology in plan and profile, geological structure, and substrate material were considered. With respect to anthropic factors, processes that produce unfavorable changes to slope stability were considered. Anthropic processes cause changes in the state of stress and affect the shear strength of materials. These processes include land use, the presence of water on the surface, and water arising from the slope profile.

The indicator "presence of instability features" is considered as a key criterion in mapping the risk of landslides to provide indications of their occurrence or imminence on the slope. This criterion was adopted in the analysis since there is evidence of a creeping process in triggering landslides at the study site.

In order to observe instability features, inspections were made at 62 points on the slope in the study area, encompassing residences and the surface area of the slope, in addition to information contained in the occurrence registries provided by the Municipal Civil Defense. 
Field inspections sought to identify information that can indicate the occurrence or the possibility of developing landslides in the area or the possibility of their occurring at the site, such as the existence of cracks in the floor and/or masonry, the inclination of rigid structures, such as retaining walls, large trees, fences, posts, and the facade of residences and subsidence of the residential floor, among other problems.

Vulnerability, as well as hazards, is an important component in risk assessment. It reflects the interaction between potentially harmful phenomena and the elements exposed to risk. Demographic density was adopted in this study as an assessment criterion of the population's exposure to the risk of landslides in the study area.

The degree of importance for each socioenvironmental indicator in risk generation was measured using the weights of the AHP method. The authors assigned these weights in collaboration with ten professionals who were not involved in the research, with a background in geological-geotechnical risk mapping, consisting of seven civil engineers, two geologists, and one geographer, 6 of whom were university professors and 4 were employed by private companies.

In order to facilitate obtaining weights by consulting specialists, they received a base document consisting of a text file and Excel spreadsheet. The document consisted of a brief presentation of the AHP technique using an explanatory text, presenting the risk indicators selected for analysis, in addition to a guide on how the electronic spreadsheet should be filled out.

After the specialists attributed the weights, the Consistency Ratio (CR) was used to analyze the consistency of the weights obtained. The specialists' assessments were considered acceptable when the CR was less than or equal to $10 \%$.

For the spatial implementation of the risk map (using geographic information system (GIS) software), explained in Figure 4, each criterion/indicator $\left(C_{i}\right)$ was transformed into a thematic map in raster format and reclassified as a function of preliminarily established subclasses. This operation intended to transform input raster cell values to the desired output values and enable linear standardization of attributes that exhibit different valuations [8].

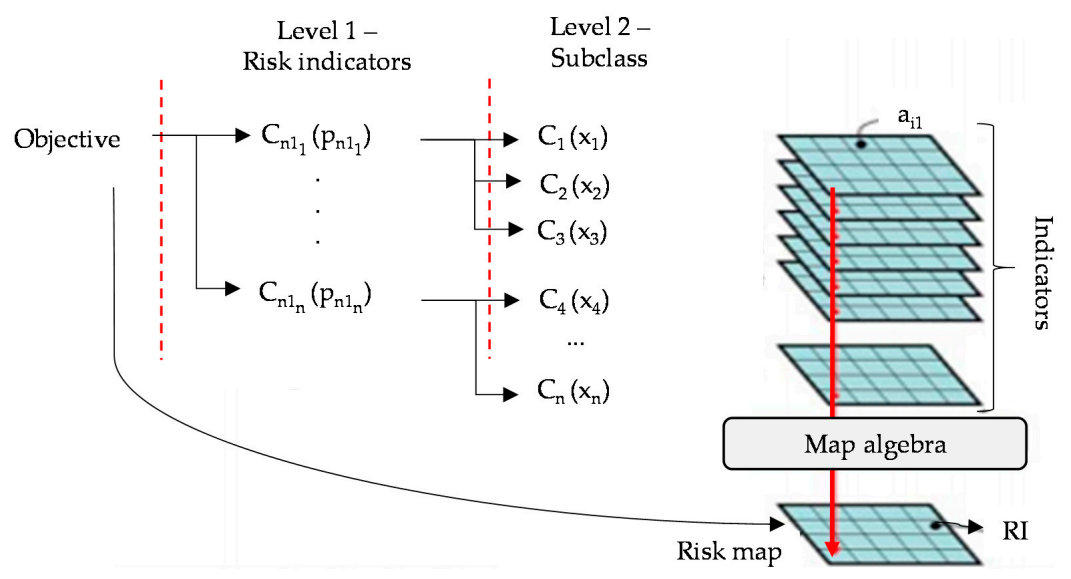

Figure 4. Schematic procedure for spatial implementation of the risk map in commercial software. Adapted from [8].

As shown in Figure 4, the criteria that influence reaching the objective (landslide risk map) were deconstructed into two hierarchical levels. Level 1 criteria $\left(C_{n 1}\right)$ are the risk indicators (slope height, slope angle, etc.) and level $2\left(C_{n 2}\right)$ are their respective subclasses. Each criterion in both levels was attributed an AHP weight ( $p_{n}$ and $x_{n}$ for levels 1 and 2, respectively).

The spatial performance $\left(a_{i}\right)$ of each cell of the mapped area was calculated by multiplying indicator weightings by the weighting of the class of the respective indicator, obtaining the risk 
indicator, as demonstrated in Equation (1), where $p$ is the weighting of the risk indicator and $\mathrm{x}$ is the weighting of the class of the respective risk indicator (subcriterion).

$$
\mathrm{RI}=\sum_{i=1}^{n} p_{i} x_{i} / 100
$$

The final risk classification was reached using a statistical-based slicing method [9], denominated here as degree of risk (DR). According to this procedure, the risk indicator for each pixel should be compared to the arithmetic mean $\left(\mu_{\mathrm{IR}}\right)$ of the risk index for all pixels, added or subtracted by half the standard deviation $(\sigma)$, as shown in Table 1.

Table 1. Criteria adopted to classify degree of risk (DR). Modified from Faria (2011).

\begin{tabular}{cc}
\hline Risk Index (RI) & (DR) \\
\hline $\mathrm{RI}<\mu_{\mathrm{RI}}-\frac{1}{2} \sigma$ & Low \\
\hline$\mu_{\mathrm{RI}}-\frac{1}{2} \sigma \leq \mathrm{RI} \leq \mu_{\mathrm{RI}}+\frac{1}{2} \sigma$ & Medium \\
\hline $\mathrm{RI}>\mu_{\mathrm{IRI}}+\frac{1}{2} \sigma$ & High \\
\hline
\end{tabular}

\subsection{Site Description}

The study area in this work is a settlement of informal origin, located at an urban hill between the Rocas and Praia do Meio neighborhoods, in the city of Natal, Rio Grande do Norte state, Brazil (Figure 5).

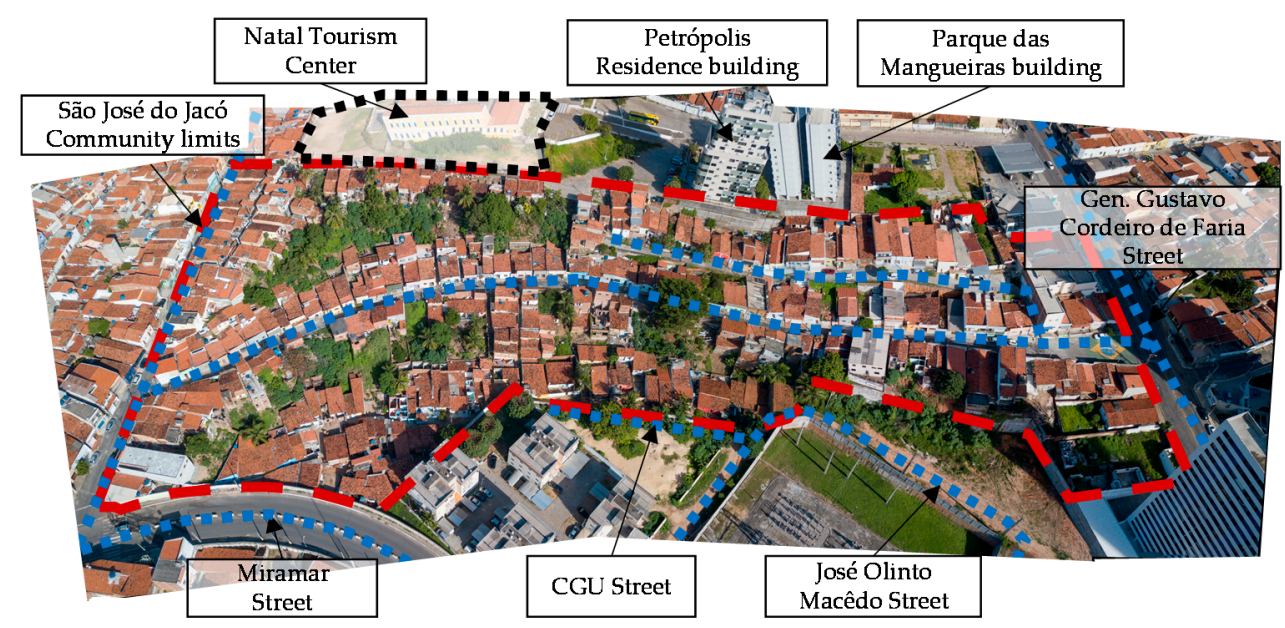

Figure 5. Aerial photograph of the São José do Jacó Community, with main streets highlighted.

The city of Natal was built in an area characterized by dune fields formed by aeolian sediments, next to the beach line-coastal trays entering the continent. The urban fabric of Natal area is, almost entirely, atop the coastal trays, which, in geological terms, correspond to the Barreiras Formation and Potengi Formation, lithological units formed by sediments of tertiary and quaternary age, in which layers of clay sands, pure sands, and silty sands are interspersed. There are also occurrences of conglomeratic layers and other strongly cemented layers.

The analyzed sector involves a 3.18 ha area and approximately 240 homes and 600 residents, according to data from the 2010 Brazil Demographic Census. The municipal macro zoning plan locates the region in a densified area and it is considered a Special Area of Social Interest Type 1—Slum [16]. Around half of the area of Rocas lies on a predominately a flat terrain, with an altitude of $5 \mathrm{~m}$ above sea level (a.s.l.), with few points where the altitude exceeds $15 \mathrm{~m}$ a.s.l. The highest elevations, in the limit region between Rocas and Praia do Meio, are occupied by the São José do Jacó Community, where the altitudes vary between $7 \mathrm{~m}$ and $37 \mathrm{~m}$ a.s.l. and the slopes between $10^{\circ}$ and $20^{\circ}$. 
The region under study has a history of slope instability. In June 2014, part of the $13 \mathrm{~m}$ high retaining structure failed and collapsed after around $50 \mathrm{~h}$ of steady rain, totaling $315 \mathrm{~mm}$. The cause of the failure is primarily associated to the lack of an efficient drainage system in the structure. Figure 6 shows photographs of the collapsed retaining structure in the community of São José do Jacó.

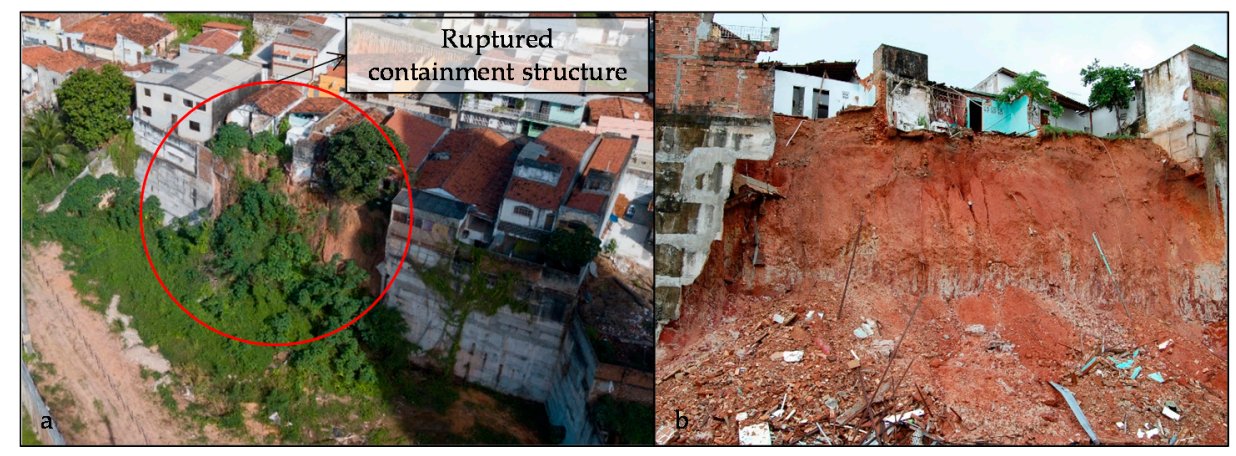

Figure 6. Area affected by the collapse of a retaining structure in the community of São José do Jacó.

In addition to this large disaster, evidence of the movement in the form of tilted trees, retaining structures and the facades of dwellings, denotes the presence of creep in full development in the community of São José do Jacó.

\section{Results and Discussion}

\subsection{Weightings Obtained by the AHP Method}

Table 2 shows pairwise comparisons, expressed by the weightings obtained for the risk indicators and their classes. These weightings represent the order of importance of each risk indicator in the occurrence of landslides processes on the urban slope occupied in the study area. Table 3 shows a summary of the sensitivity analysis for the risk indicator matrix.

Table 2. Weightings obtained for the risk indicators and their classes.

\begin{tabular}{|c|c|c|c|}
\hline Risk Indicators & Weights (\%) & Classes & Weights $(\%)$ \\
\hline \multirow{3}{*}{ Slope height } & \multirow{3}{*}{$3.21 \%$} & $\mathrm{H} \leq 10 \mathrm{~m}$ & $8.82 \%$ \\
\hline & & $10 \mathrm{~m}<\mathrm{H}<20 \mathrm{~m}$ & $24.31 \%$ \\
\hline & & $\mathrm{H} \geq 20 \mathrm{~m}$ & $66.87 \%$ \\
\hline \multirow{3}{*}{ Slope angle } & \multirow{3}{*}{$5.79 \%$} & $\mathrm{~A} \leq 10^{\circ}$ & $8.33 \%$ \\
\hline & & $10^{\circ}<\mathrm{A}<20^{\circ}$ & $19.32 \%$ \\
\hline & & $\mathrm{A} \geq 20^{\circ}$ & $72.35 \%$ \\
\hline \multirow{3}{*}{ Plant morphology } & \multirow{3}{*}{$2.11 \%$} & Convex & $12.01 \%$ \\
\hline & & Rectilinear & $13.43 \%$ \\
\hline & & Concave & $74.56 \%$ \\
\hline \multirow{3}{*}{ Profile morphology } & \multirow{3}{*}{$2.15 \%$} & Convex & $20.00 \%$ \\
\hline & & Rectilinear & $20.00 \%$ \\
\hline & & Concave & $60.00 \%$ \\
\hline \multirow{4}{*}{ Land use/cover } & \multirow{4}{*}{$8.63 \%$} & Arboreal & $6.38 \%$ \\
\hline & & Field/crop & $6.71 \%$ \\
\hline & & Urban cover & $30.77 \%$ \\
\hline & & Exposed soil & $56.15 \%$ \\
\hline \multirow{3}{*}{ Presence of surface water } & \multirow{3}{*}{$2.22 \%$} & None/Low concentration & $10.62 \%$ \\
\hline & & Medium concentration & $26.05 \%$ \\
\hline & & High concentration/Seepage line visible & $63.33 \%$ \\
\hline
\end{tabular}


Table 2. Cont.

\begin{tabular}{|c|c|c|c|}
\hline Risk Indicators & Weights (\%) & Classes & Weights (\%) \\
\hline \multirow{2}{*}{ Water emergence in the hillside profile } & \multirow{2}{*}{$11.69 \%$} & Observed & $87.50 \%$ \\
\hline & & Not observed & $12.50 \%$ \\
\hline \multirow{2}{*}{ Instability features } & \multirow{2}{*}{$19.90 \%$} & Observed & $87.50 \%$ \\
\hline & & Not observed & $12.50 \%$ \\
\hline \multirow{5}{*}{ Substrate material } & \multirow{5}{*}{$11.51 \%$} & Coastal plant eolian deposits & $7.39 \%$ \\
\hline & & Coastal non-plant eolian deposits & $46.56 \%$ \\
\hline & & Sandy and sandy-clay deposits & $19.58 \%$ \\
\hline & & Fluvial-marine deposits & $14.42 \%$ \\
\hline & & Barrier group & $12.06 \%$ \\
\hline \multirow{3}{*}{ Geological structure } & \multirow{3}{*}{$12.16 \%$} & Favorable to stability & $8.82 \%$ \\
\hline & & Unfavorable & $66.87 \%$ \\
\hline & & Not observed & $24.31 \%$ \\
\hline \multirow{4}{*}{ Demographic density } & \multirow{4}{*}{$20.64 \%$} & Inhabited area & $4.17 \%$ \\
\hline & & 0 inhab/ha $<(\mathrm{DEN}) \leq 50$ inhab/hectare & $13.30 \%$ \\
\hline & & 50 inhab/ha $<(\mathrm{DEN}) \leq 300$ inhab/hectare & $26.76 \%$ \\
\hline & & $(\mathrm{DEN})>300$ inhab/hectare & $55.77 \%$ \\
\hline
\end{tabular}

Table 3. Sensitivity analysis of reciprocal matrix risk indicators.

\begin{tabular}{cc}
\hline \multicolumn{2}{c}{ Sensitivity Analysis } \\
\hline Matrix order & 11.00 \\
$\lambda_{\max }{ }^{1}$ & 12.09 \\
$\mathrm{CI}^{2}$ & 0.1086 \\
$\mathrm{CR}^{3}$ & $7.10 \%$ \\
\hline mum eigenvalue; ${ }^{2} \mathrm{CI}$ : Consistency Index; ${ }^{3} \mathrm{CR}$ : Consistency Ratio.
\end{tabular}

The Consistency Ratio (CR) was less than $10 \%$ for the risk indicator matrix, as recommended by the AHP methodology. This value indicates an acceptable consistency level in the comparisons performed.

Two other indications of reliability in the specialists' judgements are a CI near zero and $\lambda_{\max }$ value near the order of the comparison matrix. The latter derives from the corollary adopted in the AHP method developed by [17] and considers that a reciprocal matrix A, with positive input values only consistent if $\lambda_{\max }=\mathrm{n}$.

\subsection{Risk Mapping}

Given the two elements essential to risk formulation —-the hazard and the vulnerability—distinct products were created for each of these elements and combined following the national and international trend to produce the risk map. Figure 7 illustrates the process of obtaining intermediate maps and the risk map.

\subsubsection{Hazard Map}

The hazard map created using the AHP method (Figure 8) showed that most of the study area $(48 \%)$ lies in a high-hazard zone for the occurrence of landslides, $45.3 \%$ is in the low-hazard category, and only $6.7 \%$ is considered a medium hazard.

To establish a correlation between spatialization of the hazard classes obtained for the slope and each of the indicators assessed, the contribution of the natural physical traits of the area was analyzed separately from contributions of anthropic factors using a susceptibility map (Figure 9).

Of the six parameters used to create the susceptibility map (slope height, slope angle, plant and profile morphology, substrate material, and geological structure), the slope angle was the factor that influenced spatialization the most, primarily due to the weighting attributed to it by the AHP method. 


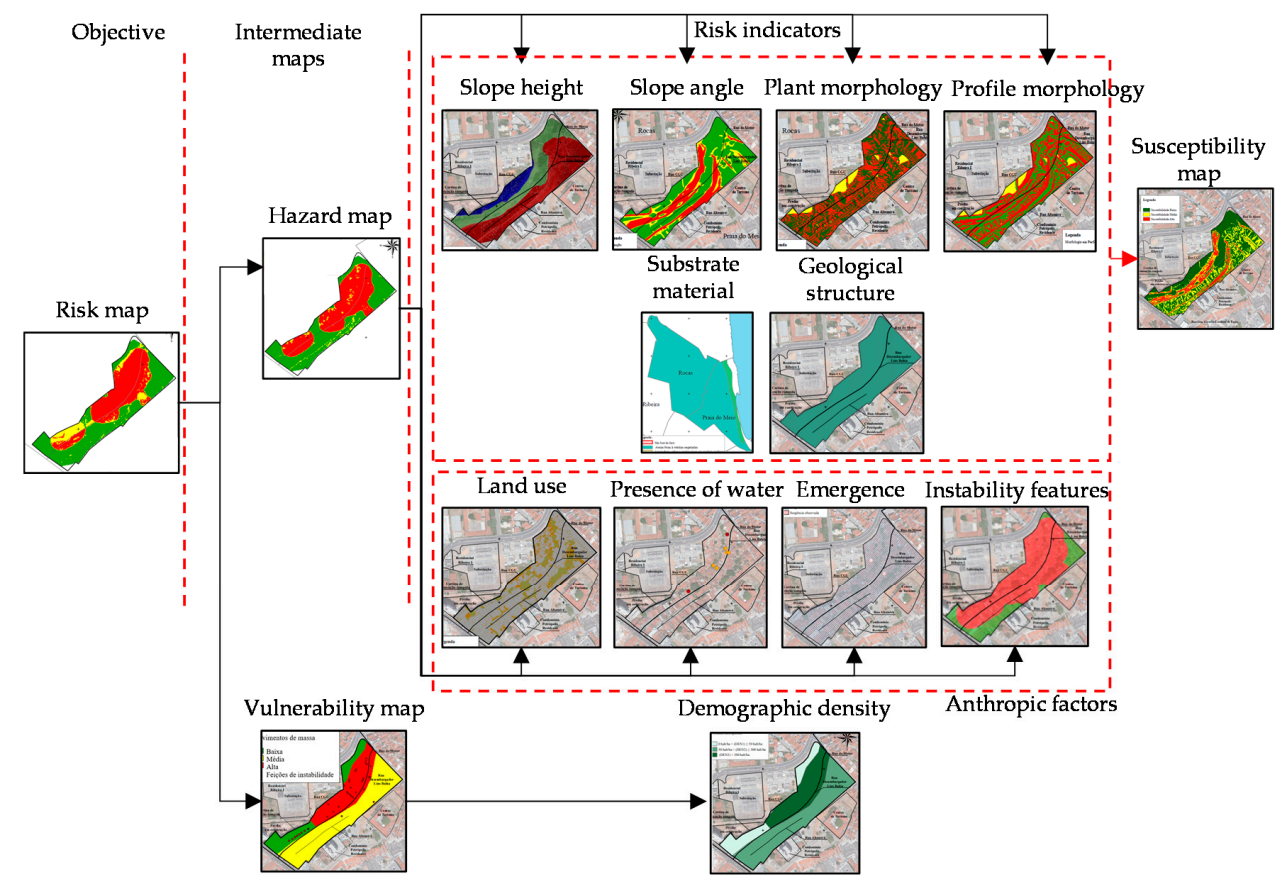

Figure 7. Schematic model for obtaining the intermediate hazard and vulnerability maps as well as the risk map for the study area.

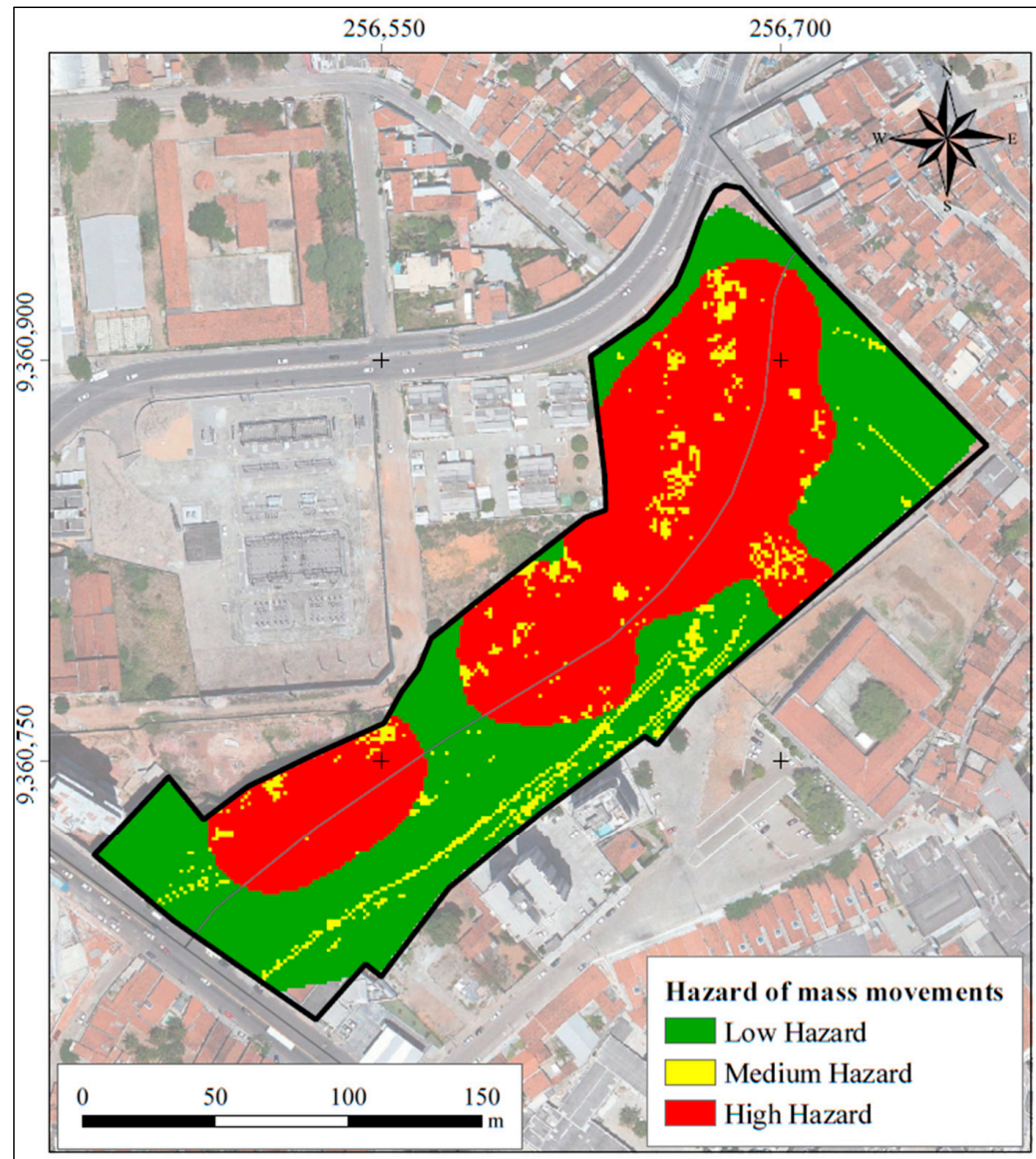

Cartographic properties: Datum SIRGAS 2000 / UTM coordinates / Zone 25S

Figure 8. Landslide hazard map produced for the study area. 
The analysis of the contribution of anthropogenic factors (land use/cover, presence of surface water, water emergence on the hillside profile, and instability features) shows that the presence of instability features governed the spatial arrangement of hazard classes, raising it to the "high" category in areas where scars were observed-i.e., signs of previous slope failure were visible.

Comparison between the results of the susceptibility and hazard maps, in which anthropic action was included, revealed that if only the natural physical traits were analyzed, the study area would not be highly susceptible to landslides. However, anthropogenic use and occupation of the slope is the main factor that poses hazard to the resident population, making it hazardous for human occupation. Thus, since the region under study is an occupied slope, it is important that public entities monitor it in order to prevent loss of life and property.

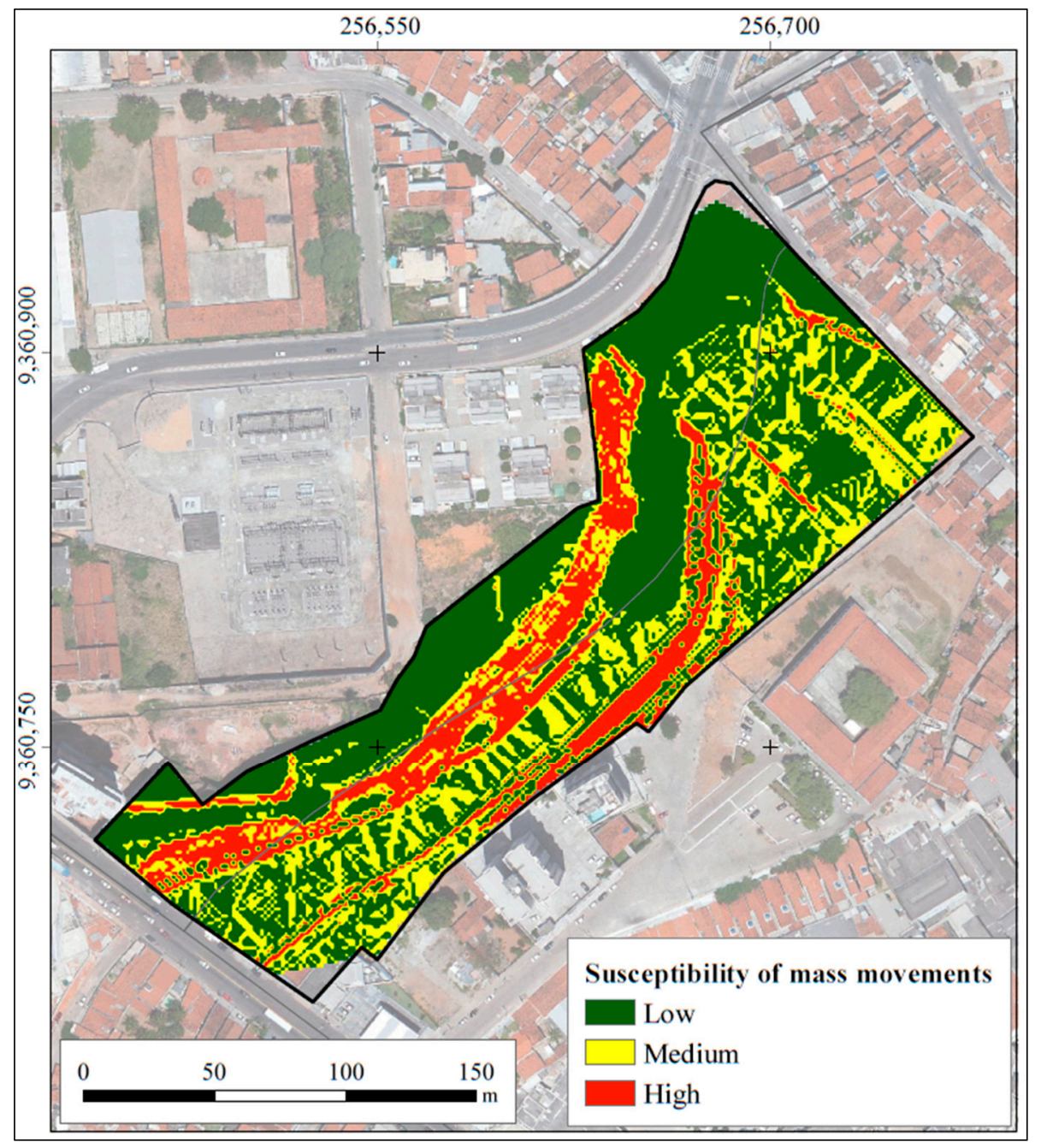

Figure 9. Landslide susceptibility map produced for the study area.

\subsubsection{Vulnerability Map}

The vulnerability map produced by a procedure similar to that described for risk is presented in Figure 10. A large part of the study area exhibited medium (50.97\%) to high (32.01\%) vulnerability, generally associated with a significant number of residential plots occupied by substandard housing and high population density, located on sloping terrain that would require more appropriate building techniques, and more space between residences. 


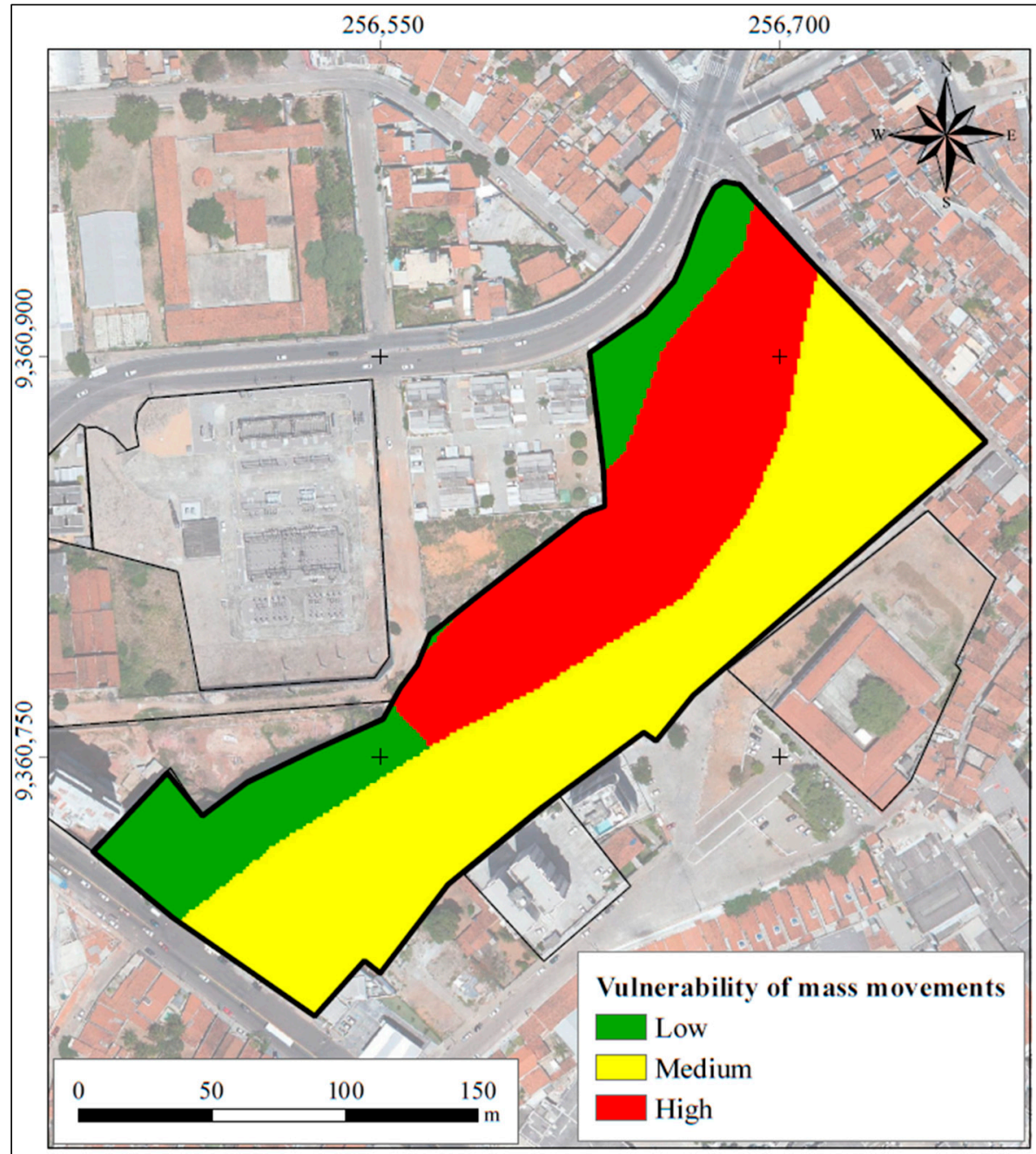

Cartographic properties: Datum SIRGAS 2000 / UTM coordinates / Zone 25S

Figure 10. Vulnerability map produced for the study area.

Despite the fact that the financial status of the population that inhabit the study area was not considered in the weighting attribution phase of the AHP method, it is important to include it in vulnerability analysis, given that this trait affects how residents deal with socioenvironmental disasters such as landslides. There is a general agreement that households with higher income tend to have better built homes and are thereby better equipped to withstand extreme natural events.

Based on this hypothesis, assessment of income distribution, obtained from [18] shows that 50\% of the private dwellings in the study area are occupied by low-income families, that is, those earning up to one-half the minimum monthly wage ( $\approx$ USD 125.00 ).

It is important to observe, therefore, that the sector with more disadvantaged families-that is, in poverty or extreme poverty-contains the highest demographic density (more than 300 inhabitants per hectare). In addition to having greater difficulty in evacuating the population in the event of a disaster in this region, the inhabitants are also more vulnerable due to the infrastructure characteristics of their dwellings and the surrounding area.

\subsubsection{Risk Map}

The final element of the mapping process is illustrated in Figure 11. 


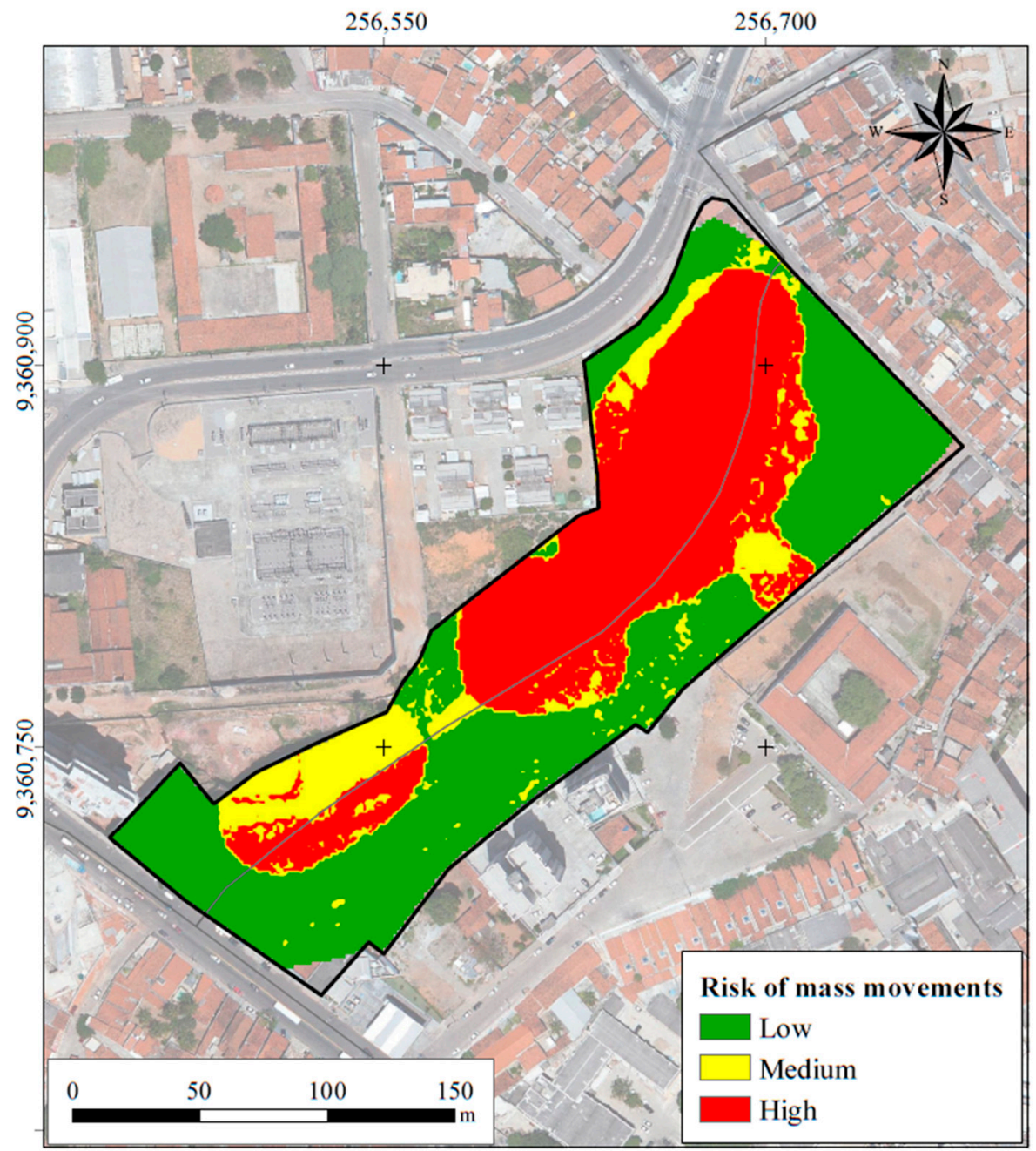

Cartographic properties: Datum SIRGAS 2000 / UTM coordinates / Zone 25S

Figure 11. Risk map of the study area.

Risk mapping shows that the area exhibits a degree of slope instability risk ranging from low to high. The low-risk category accounted for $46 \%$ of the total area, followed by the high-risk $(41 \%)$ and medium-risk groups (13\%), which represents about 600 people under risk of landslides in an area of approximately 3.2 ha.

In general, the low-risk areas were concentrated mainly on Altamira Street and the first portion of Desembargador Lins Bahia Street (Figure 12), and exhibited geomorphological conditions that display low landslide potential, with a slope height below $20 \mathrm{~m}$, low slope angle (less than $10^{\circ}$ ), convex/divergent plant morphology, and rectilinear and/or convex profile morphology.

With respect to the contribution of anthropic interferences in these areas, there is an absence or reduction in instability, no water on the slope surface or emergence points along the slope profile, which may be related to the existence, albeit incipient, of sewer, water supply, and rainwater drainage systems. In addition, these lower risk areas are characterized by low and medium vulnerability, due to a lower demographic density and households with higher incomes when compared to medium or high-risk regions, which exhibit a direct relation with better infrastructure and consequently with the response to a landslide. 


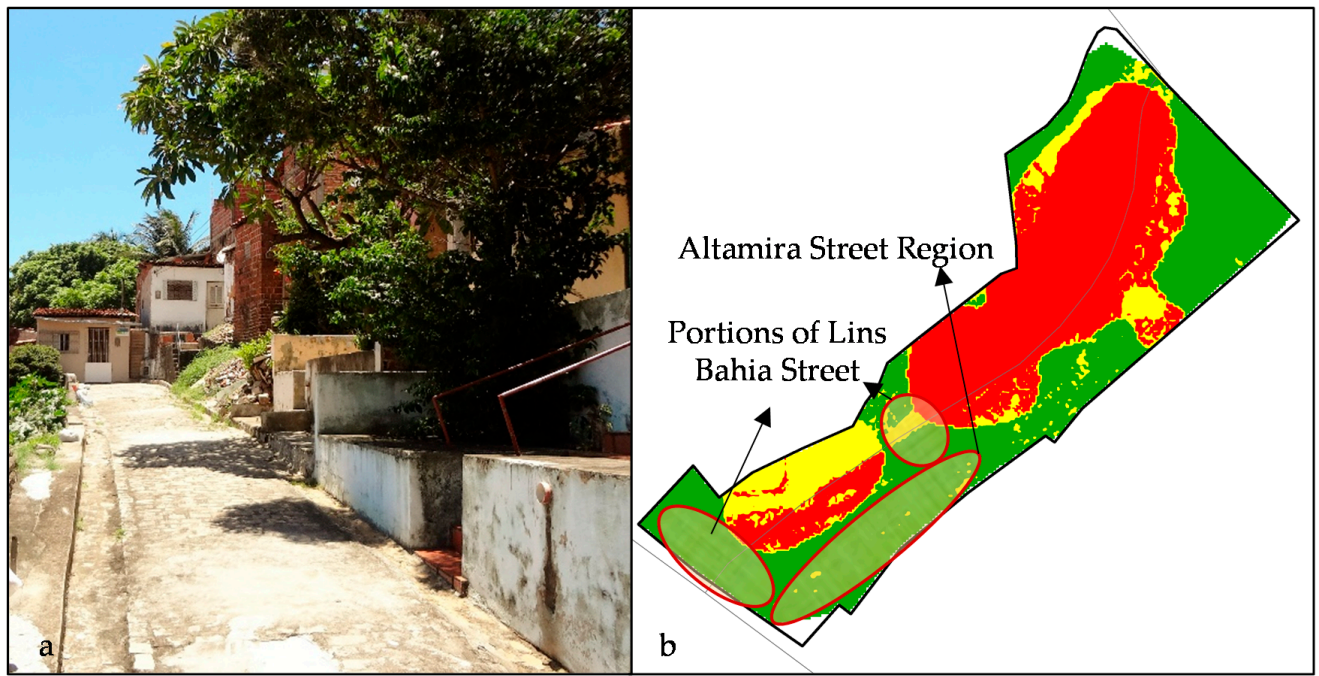

Figure 12. Low-risk regions identified in the assessment: photo of Altamira Street (a) with the surrounding area highlighted in (b).

In the slope regions classified as medium risk, the greatest contribution to obtaining this degree was the type of anthropic interference on the slope and the influence of vulnerability. The unfavorable contribution of human interventions in the area is evident on Desembargador Lins Bahia Street, where the risk of landslides rose from low to high (Figure 13a) due to the rupture of a retaining structure, which caused the emergence of instability features, which are extremely important in the analysis of hazard and risk.

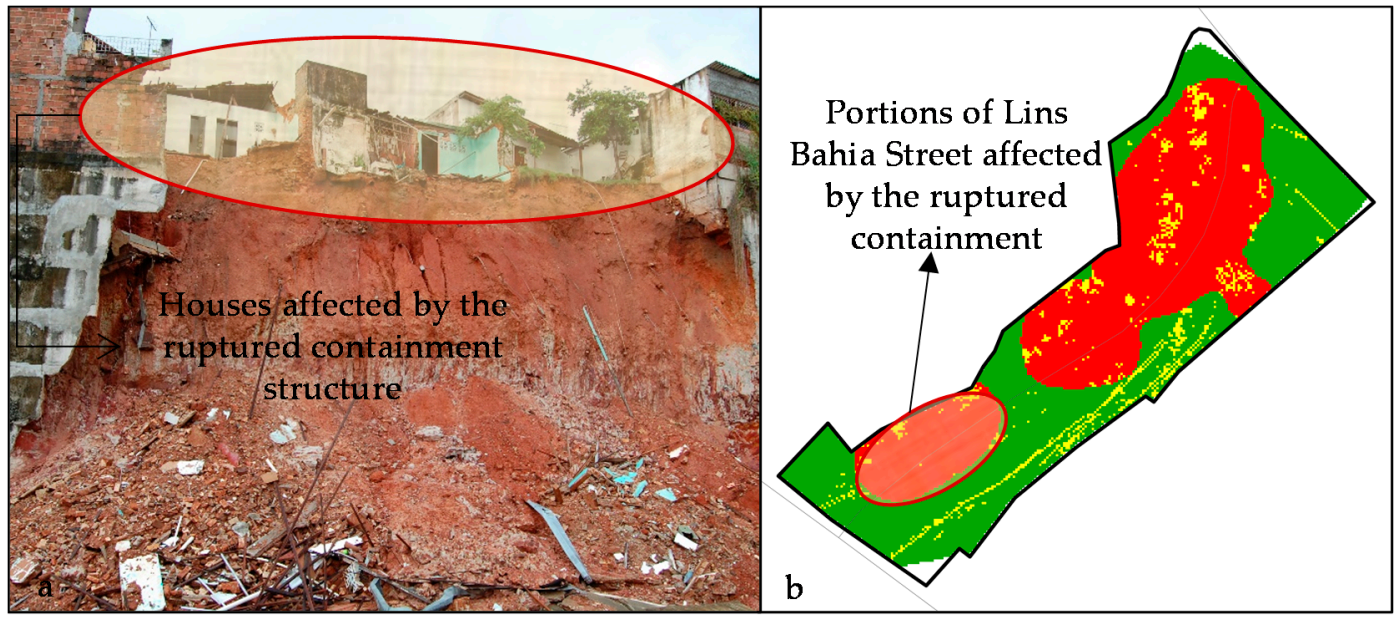

Figure 13. Unfavorable contribution of human interventions in the area near the containment curtain in obtaining medium risk: (a) portion of Lins Bahia Street with high risk; (b) houses affected by the ruptured containment structure.

In high-risk areas, nearly $50 \%$ of the region analyzed, the geological conditions exhibited a greater potential of developing landslides, with slope height values between 10 and $20 \mathrm{~m}$ and higher than $20 \mathrm{~m}$, a high slope angle (more than $20^{\circ}$ ), predominantly convergent plant morphology, concave slope profile, and areas with little or no plant cover and even impermeable surfaces. In relation to the anthropic interventions on the slope, field visits revealed a large number of haphazard cuts. These cuts were made to allow construction of access roads to dwellings located at the top, foot, and slope of the hillside. Figure 14 illustrates this situation. 


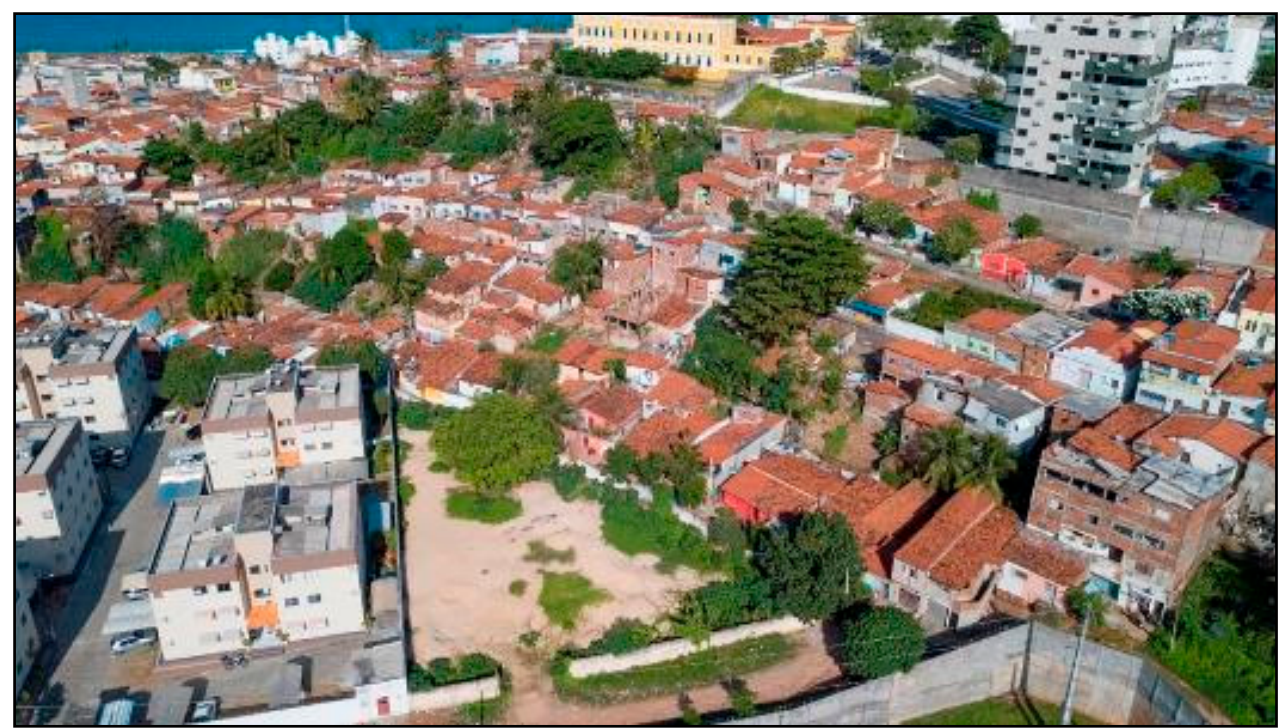

Figure 14. Construction of homes halfway up the slope.

Human action in the area is also reflected in the disposal of waste and rubble on the slope (Figure 15). According to [19], these materials are heterogeneous and geotechnically quite unstable. Waste deposition increases the weight on the slope and contributes to the triggering of landslides.

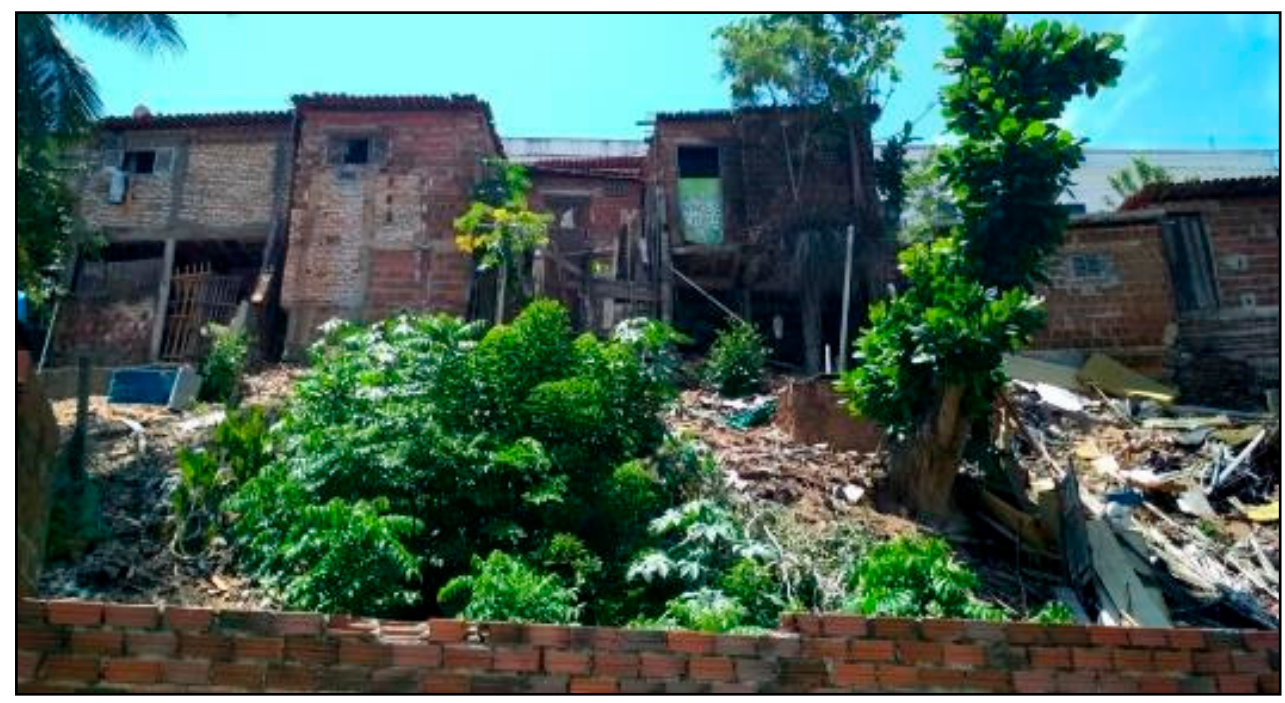

Figure 15. Waste and rubble deposition on the hillside within the site area.

Leaks in water supply and sewer pipes were also observed within the site area (Figure 16a,b). Furthermore, despite the installation of a sanitary sewer in 2014, many residents of high-risk areas continue to use septic tanks and sinkholes as a sewer system.

Since sinkholes can serve as points of water concentration [20], the more numerous and closer together they are, the greater the risk of landslides they pose to the nearest dwellings. Finally, the presence of significant signs of instability, as illustrated in Figure 17a,b, including vertical, horizontal and diagonal cracks in floors and/or masonry, and the inclination of rigid structures, such as retaining walls, large trees, fences, posts and sinking floors, were determining factors for the high-risk classification in some sectors of Jacó. 


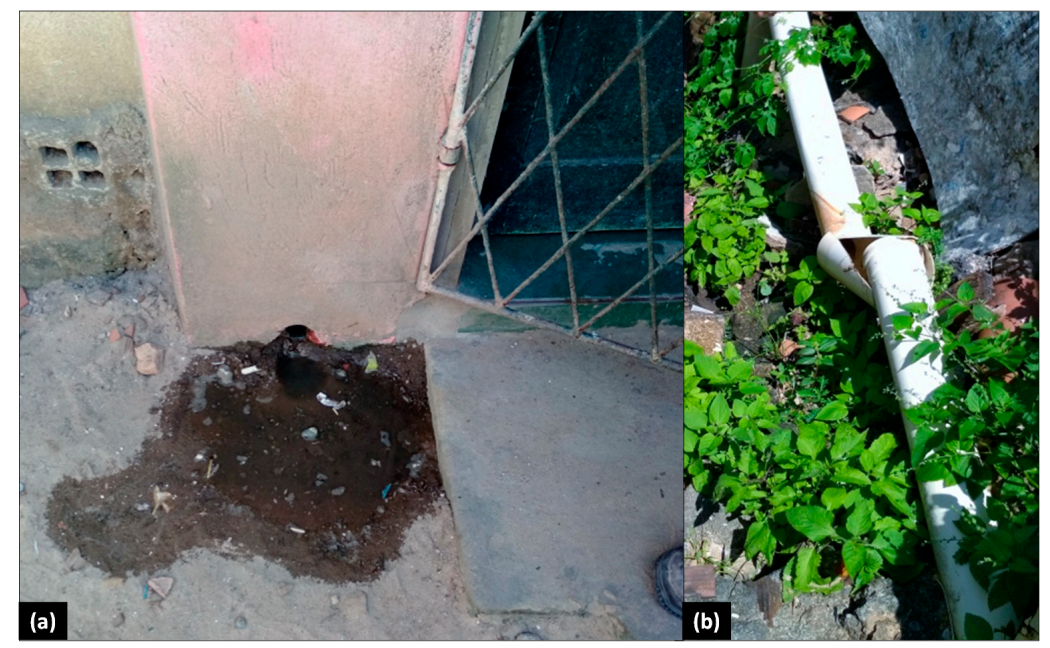

Figure 16. (a) Presence of water on the slope surface; (b) Damaged drain pipe.

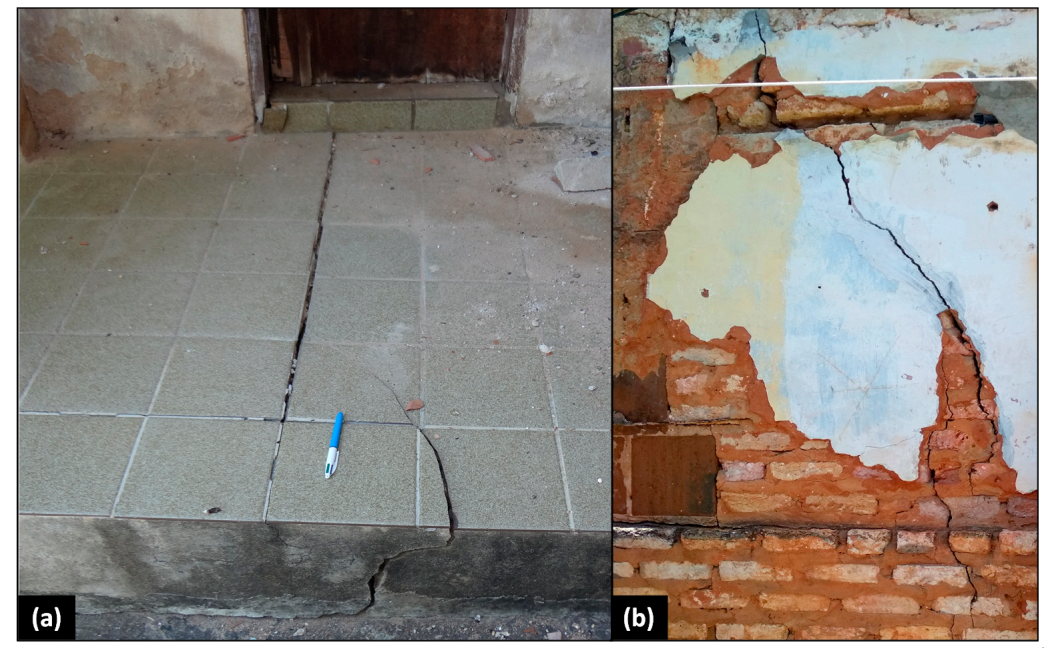

Figure 17. (a) Cracks in the floors; (b) Vertical, horizontal, and diagonal cracks in the masonry of residences in the study area.4. Discussion and Conclusions.

This study aimed to assess and map the risk of landslides in an inhabited urban slope in the municipality of Natal, Rio Grande do Norte state, Brazil, applying an adapted version of Faria's (2011) qualitative-quantitative risk analysis methodology. This methodological proposal incorporated the AHP decision-making tool into a qualitative method of risk analysis.

Mapping the risk of landslides is an essential tool for the definition of land use and occupation policies in urban areas (e.g., [21]). The methodology applied in this study falls well within the range of available techniques used for susceptibility and hazard mapping of landslides [22]. Based on the classification of mapping techniques into qualitative, semi-quantitative and qualitative-where the qualitative techniques are supported by geomorphic analysis and the analysis of landslide inventory that occurred in the studied region while, on the other hand, semi-quantitative techniques are based on multicriteria decision analysis, and the quantitative techniques include statistical and probabilistic analysis, a deterministic approach, and artificial intelligence - the method used in this study can be classified as semi-quantitative.

Regardless of the method used, the inference of risk of landslides can only be made from knowledge of the types and mechanisms acting in the area. In this sense, Ref. [23], based on a recommendation from the Joint Technical Committee on Landslides and Engineered Slopes (JTC-1), highlighted that in the risk mapping the landslide inventory map is essential. On the other hand, there are situations in 
which there are no files with a record of landslide occurrences, or these records are not reliable where expert evaluations can be used [22].

In the present work, although an inventory map has not been presented, the typology and instability mechanisms have been interpreted from the Civil Defense database in Natal and from the experience reported in previous works developed in the region [4,24-27]. These aspects were considered in the risk map using the presence of instability features indicator. This approach justified the consultation with specialists to establish the weights attributed to the socioenvironmental indicators which, in turn, suggested an acceptable consistency level in the performed comparisons as well as coherence in the order of importance obtained for the attributes and their subclasses, when comparing the research data with information extracted in field visits.

Favorable results in using the combination of GIS and AHP method in terms of mapping areas of susceptibility, hazard, and/or risk were obtained by $[8,28,29]$. Ref. [8] emphasize that although this type of methodology is considered subjective, the fact that it allows the incorporation of experts' opinions through the attribution of weights to socioenvironmental indicators and adopts a sensitivity analysis to assess the assigned weights has led to reliable results, from larger work scales at the local level, to small mapping scales at the national level.

The risk map obtained by applying an adapted version of [9] demonstrated that the study area exhibits a high degree of slope instability risk in approximately half of the São José do Jacó settlement. This region showed the existence of a number of factors that increase the possibility of landslides, including anthropic interventions in the area, the presence of significant instability features, and a considerable number of residential plots occupied by substandard housing, in addition to a high population density.

This analysis demonstrated that the geomorphological, geological, and geotechnical constraints were less relevant for spatializing risk in the community of São José do Jacó, and that the most important contribution for the occurrence of landslides in the area is the anthropic interference on the slope and the influence of demographic density, a socioenvironmental indicator representative of the elements at risk.

Bearing in mind that the wider study area is relatively densely populated, and in order to prevent loss of life and material damage, civil engineers, land planners, and environmental managers can use the results of this study to pinpoint the risk areas as well as monitor the most critical indicators in the long term. This monitoring program, coupled with an adequate maintenance program for the existing infrastructure and control of any new built infrastructure, can contribute towards the sustainability of the infrastructure, environment, and of the community inhabiting it.

The comparison between the four studies conducted in the São José do Jacó settlement indicated a critical risk situation for the local population, primarily in the form of landslides, causing possible economic, environmental and above all, social harm. The three other studies that investigated the area [30-32] showed similar results, underscoring the area between Desembargador Lins Bahia and CGU Streets as high-risk for the occurrence of landslides.

The observation of consistent similarities between the results of this work and the other mappings already carried out in the study area, as well as the comparison of the mapping result with the data and information obtained from the field visits, were important to validate the acceptability and accuracy of the results achieved by applying the qualitative and quantitative model of [9], which means that a similar approach can be used in the other occupied urban slopes in the city of Natal, or in regions with physical and social characteristics similar to those observed in the study area.

Ref. [21] reviewed 768 scientific articles produced between 1999 and 2018, whose main theme involved the mapping of susceptibility, hazard or risk of landslides, in order to observe, in addition to other aspects, trends in the type of model used in these analyses. Among the several commonly used model types, the AHP method has shown a growth trend in its use over the past 20 years.

Despite the clarity and validation of the results of this study, as well as the flexibility of the model, Ref. [33] points out an important limitation of the method, linked to the inability to determine the 
uncertainties related to the selection, comparison, and ranking of the multiple criteria analyzed by the experts. Thus, in an attempt to mitigate this limitation, future work should focus on combining the AHP method with another technique, creating integrated models that preserve and integrate the advantages of the models that have been combined.

Author Contributions: Conceptualization, L.B., O.d.F.N. and O.S.J.; Methodology, L.B., O.d.F.N., O.S.J. and S.M.; Investigation, L.B., O.d.F.N. and O.S.J.; Writing-original draft, L.B., O.d.F.N., O.S.J. and S.M.; Writing-review \& editing, L.B., O.d.F.N., O.S.J. and S.M.; Funding acquisition, L.B., O.d.F.N., O.S.J., S.M.; Resources, L.B., O.d.F.N. and O.S.J., S.M.; Supervision, L.B., O.d.F.N., O.S.J. and S.M. All authors have read and agreed to the published version of the manuscript.

Funding: This research was funded by Higher Education Personnel Improvement Coordination—Brazil (CAPES).

Acknowledgments: The authors are grateful to the support provided by the Brazilian research sponsorship organizations CNPq (National Council for Scientific and Technological Development), CAPES (Higher Education Personnel Improvement Coordination) and the Municipal Civil Defense team of Natal, Brazil. The authors are also indebted to the Graduate Program Civil Engineering of the Federal University of Rio Grande do Norte (PEC-UFRN).

Conflicts of Interest: The authors declare no conflict of interest.

\section{References}

1. International Federation of Red Cross and Red Crescent Societies. World Disasters Report Focus on Urban Risk. 2010. Available online: https://www.ifrc.org/en/publications-and-reports/world-disasters-report/wdr2010// (accessed on 17 September 2020).

2. Universidade Federal de Santa Catarina; Centro Universitário de Estudos e Pesquisas sobre Desastres. Atlas Brasileiro de Desastres Naturais: 1991 a 2012, 2nd ed.; CEPED UFSC: Florianópolis, Brazil, 2013.

3. Tominaga, L.K.; Santoro, J.; Amaral, R. Desastres Naturais: Conhecer Para Prevenir, 1st ed.; Instituto Geológico: São Paulo, Brazil, 2009.

4. Santos Junior, O.F.; Severo, R.N.F.; Freitas Neto, O. Movimentos de massas em encostas na cidade de Natal/RN. In Willy Lacerda: Doutor no Saber e Na Arte De Viver, 1st ed.; Outras Letras: Rio de Janeiro, Brazil, 2016; Volume 1, pp. 468-478.

5. Australian Geomechanics Society; Sub-Committee on Landslide Risk Management. Landslide Risk Management Concepts and Guidelines. Aust. Geomech. J. News Aust. Geomech. Soci. 2002, 37, 1-44.

6. Van Westen, C.J.; Van Asch, T.W.J.; Soeters, R. Landslide hazard and risk zonation—Why is it still so difficult? Bull. Eng. Geol. Environ. 2005, 65, 167-184. [CrossRef]

7. Fell, R.; Ho, K.K.S.; Lacasse, S.; Leroi, E. State of the Art: A framework for landslide risk assessment and management. In Landslide Risk Management; Hungr, O., Feel, R., Couture, R., Eberhardt, E., Eds.; Taylor and Francis Group: London, UK, 2005; pp. 3-26.

8. Abella, E.A.C.; Van Westen, C.J. Generation of a landslide risk index map for Cuba using spatial multi-criteria evaluation. Landslides 2007, 4, 311-325. [CrossRef]

9. Faria, D.G.M. Mapeamento de Perigo de Escorregamentos em Áreas Urbanas Precárias Brasileiras Com a Incorporação do Processo de Análise Hierárquica (AHP). Ph.D. Thesis, University of São Paulo, São Paulo, Brazil, 2011.

10. Faria, D.G.M.; Augusto Filho, O. Aplicação do Processo de Análise Hierárquica (AHP) no Mapeamento de Perigo de Escorregamentos em Áreas Urbanas. Rev. Inst. Geol. 2013, 34, 23-44. [CrossRef]

11. Franek, J.; Kresta, A. Judgment Scales and Consistency Measure in AHP. Procedia Econ. Financ. 2014, 12, 164-173. [CrossRef]

12. Ministério das Cidades. Instituto de Pesquisas Tecnológicas_IPT. Mapeamento de Riscos em Encostas e Margem de Rios; Ministério das Cidades: Brasilia, Brazil; Instituto de Pesquisas Tecnológicas-IPT: Brasília, Brazil, 2007.

13. Saaty, T.L. How to Make a Decision: The Analytic Hierarchy Process. Eur. J. Oper. Res. 1990, 48, 9-26. [CrossRef]

14. Saaty, T.L. Decision making with the analytic hierarchy process. Int. J. Serv. Sci. 2008, 1, 83-98. [CrossRef]

15. Saaty, R.W. The analytic hierarchy process-What it is and how it is used. Math. Model. 1987, 9, 161-176. [CrossRef] 
16. Sobrinha, M.D.P.B.; Duarte, M.C.S.; Lélis, R.L.S.; Wanderley, M.U. Vivências, troca de saberes e formação cidadã para o direito à cidade: Experiências do Projeto Motyrum-UFRN, de educação popular em direitos humanos, na Comunidade do Jacó, em Natal/RN. In Proceedings of the Anais XVIII ENANPUR 2019, Encontro Nacional da Associação Nacional de Pós-Graduação e Pesquisa em Planjemanento Urbano e Regional, Natal, Brazil, 27-31 May 2019.

17. Saaty, T.L. A scaling method for priorities in hierarchical structures. J. Math. Psychol. 1977, 15, $234-281$. [CrossRef]

18. Instituto Brasileiro de Geografia e Estatística-IBGE. Características da População e dos Domicílios: Resultados do Universo; IBGE: Rio de Janeiro, Brazil, 2011.

19. Wiggers, M.M. Zoneamento das Áreas de Risco a Movimentos de Massa no Perímetro Urbano do Município de Caxias do Sul (RS). Master's Thesis, Federal University of Rio Grande do Sul, Porto Alegre, Brazil, 2013.

20. Alheiros, M.M.; Souza, M.A.A.; Bitoun, J.; Medeiros, S.M.G.M.; Amorim Júnior, W.M. Manual de Ocupação dos Morros da Região Metropolitana do Recife; FIDEM: Recife, Brazil, 2003.

21. Lee, S. Current and Future Status of GIS-based Landslide Susceptibility Mapping: A Literature Review. Korean J. Remote Sens. 2019, 35, 179-193. [CrossRef]

22. Shano, L.; Raghuvanshi, T.K.; Meten, M. Landslide susceptibility evaluation and hazard zonation techniques-A review. Geoenviron. Disasters 2020, 7, 1-19. [CrossRef]

23. Cascini, L. Applicability of landslide susceptibility and hazard zoning at different scales. Eng. Geol. 2008, 102, 164-177. [CrossRef]

24. Santos, O.F., Jr.; Jesus, A.P.; Macêdo, C.M.H.; Amaral, R.F. Mapeamento de Áreas de Risco de Movimentos de Massas em Encostas Formadas por Dunas na Cidade de Natal. In Proceedings of the Anais XI Congresso Brasileiro de Mecânica dos Solos e Engenharia Geotécnica, Brasília, Brazil, 6-10 November 1998; pp. 521-527.

25. Barbosa, N.; Taquez, D.; Santos, O., Jr.; Freitas Neto, O.; Scudelari, A. The Effect of Basal Erosion on Sea Cliff Stability. J. Coast. Res. 2020, 95, 362-366. [CrossRef]

26. Silva, B.M.F.; Santos , O.F., Jr.; Neto, O.F.; Scudelari, A.C. Erosão em Falésias Costeiras e Movimentos de Massa no Rio Grande do Norte, Nordeste do Brasil. Geociências 2020, 39, 447-461. [CrossRef]

27. Souza, P.L., Jr.; Santos, O.F., Jr.; Fontoura, T.B.; Freitas Neto, O. Drained and Undrained Behavior of an Aeolian Sand from Natal, Brazil. Soils Rocks 2020, 43, 263-270. [CrossRef]

28. Lorentz, J.F.; Calijuri, M.L.; Marques, E.G.; Baptista, A.C. Multicriteria analysis applied to landslide susceptibility mapping. Nat. Hazard 2016, 83, 41-52. [CrossRef]

29. El Jazouli, A.; Barakat, A.; Khellouk, R. GIS-multicriteria evaluation using AHP for landslide susceptibility mapping in Oum Er Rbia high basin (Morocco). Geoenviron. Disasters 2019, 6, 3. [CrossRef]

30. Prefeitura do Natal; Secretaria Municipal de Meio Ambiente e Urbanismo-SEMURB. Plano Municipal de Gerenciamento de Riscos: Relatório Final_Volume 1; Acquatool Consultoria: Natal, Brazil, 2008.

31. Silva, E.E.S.; Almeida, L.Q.; Macedo, Y.M. Uso de metodologia analítica para mapeamento de exposição ao risco de deslizamento na comunidade de São José do Jacó Natal-RN. Rev. Geociênc. Nordeste 2016, 1, 58-73.

32. Bezerra, L.T.V. Mapeamento de Risco/perigo de Movimentos de Massa e Avaliação da Estabilidade das Encostas na Comunidade São José do Jacó, em Natal/RN. Bachelor's Thesis, Federal University of Rio Grande do Norte, Natal, Brazil, 2016.

33. Zhou, S.; Chen, G.; Fang, L.; Nie, Y. GIS-Based Integration of Subjective and Objective Weighting Methods for Regional Landslides Susceptibility Mapping. Sustainability 2016, 8, 334. [CrossRef]

Publisher's Note: MDPI stays neutral with regard to jurisdictional claims in published maps and institutional affiliations.

(C) 2020 by the authors. Licensee MDPI, Basel, Switzerland. This article is an open access article distributed under the terms and conditions of the Creative Commons Attribution (CC BY) license (http://creativecommons.org/licenses/by/4.0/). 